\title{
Дифференциация частиц золота из продуктов гравитационного обогащения руд Тарданского месторождения
}

\author{
А.Ш. Хусаинова ${ }^{1}$, В.А. Наумов ${ }^{2,3}$, О.Б. Наумова ${ }^{2}$ \\ ${ }^{1}$ Институт геологии и минералогии им. В.С. Соболева СО РАН, 630090, Новосибирск, про- \\ спект Академика Коптюга, 3. E-mail: khusainova@igm.nsc.ru \\ ${ }^{2}$ Пермский государственный национальный исследовательский университет, 614990, Пермь, \\ ул. Букирева, 15. E-mail: poisk@psu.ru \\ ${ }^{3}$ Естественно-научный институт Пермского государственного национального исследователь- \\ ского университета, 614005, Пермь,ул. Генкеля, 4.E-mail: naumov @psu.ru \\ (Статья поступила в редакциию 19 апреля 2019 г.) \\ Проведены анализ, обобщение и сравнение материалов по содержанию, гранулометрическому и химиче- \\ скому составу, морфологии золота рудного месторождения Тардан и «хвостов» гравитационного обога- \\ щения коренных руд. В отвал поступает золото с меньшей гидравлической крупностью, чем у основной \\ части рудного золота. Эволюция преобразования золота в экзогенной среде, а именно формирование его \\ гранулометрической структуры и химического состава, прямо зависит от золота, поступающего из при- \\ родного источника, технологии отработки и физико-химических и биогенных условий среды. \\ Ключевые слова: техногенез, гипергенез, техногенные отвалы, самородное золото.
}

DOI: $10.17072 /$ psu.geol.18.3.276

\section{Введение}

В результате масштабной разработки рудных и россыпных месторождений золота образовалось большое количество «отходов» производства. Данные объекты представляют практический и научный интерес, поскольку являются источником вещества для вторичного производства (Wierchowiec et al., 2009, 2018; Chapman et al., 2016; Myagkaya et al., 2016; Наумов и др., 2018) и позволяют решить фундаментальную проблему рудной геологии и геохимии - «выяснение условий, источников и механизмов формирования рудных концентраций металлов в гипергенной среде» (Петровская, 1973; Николаева и др., 2003; Наумов, 2010; Жмодик и др., 2012; Craw et al., 2015; Shuster et al., 2018).

Деятельность человека при добыче и обогащении полезных ископаемых, рассматриваемая нами как геологический процесс техногенеза, способствует ускорению природных процессов - разрушению, миграции и осаждению вещества в экзогенной среде. Авторы на примере отвала золоторудного месторождения Тардан попытались выяснить механизмы преобразования свободного гравитационного золота и оценить влияние техногенных и природных факторов на формирование объекта и трансформацию золота.

Актуальность данных исследований заключается в том, что изучение типоморных признаков золота позволяет определить условия его образования и влияние факторов внешней среды. Поверхность золота весьма чувствительна к воздействию условий минералообразующей среды, агентов химического выветривания, обстановки и характера миграции частиц, литогенетических процессов из-за своих уникальных физических и химических свойств (Николаева и др., 2003; Осовецкий, 2012).

\section{Объект исследования}

Объект исследования расположен в Алтае-Саянской складчатой области, в 78 км от столицы Республики Тыва г. Кызыла.

На первом этапе обогащения руд (после дробления и измельчения) проводили гравитационное обогащение золота на концентрационных столах - снимали относительно крупное золото в виде «золотой головки». Хвосты обогащения сливали в отвалнакопитель для последующего цианирования при кучном выщелачивании. 
В плане отвал выглядит как своеобразный конус выноса с несколькими зонами распределения вещества (рис. 1): устьевая зона (зона I), средняя часть (зона II) и периферия (зона III). Согласно отечественным классификациям отвалов (Наумов, 1994; 2010; Макаров, 2001; Шило, 2002), объект относится к намывному типу техногенной фации.

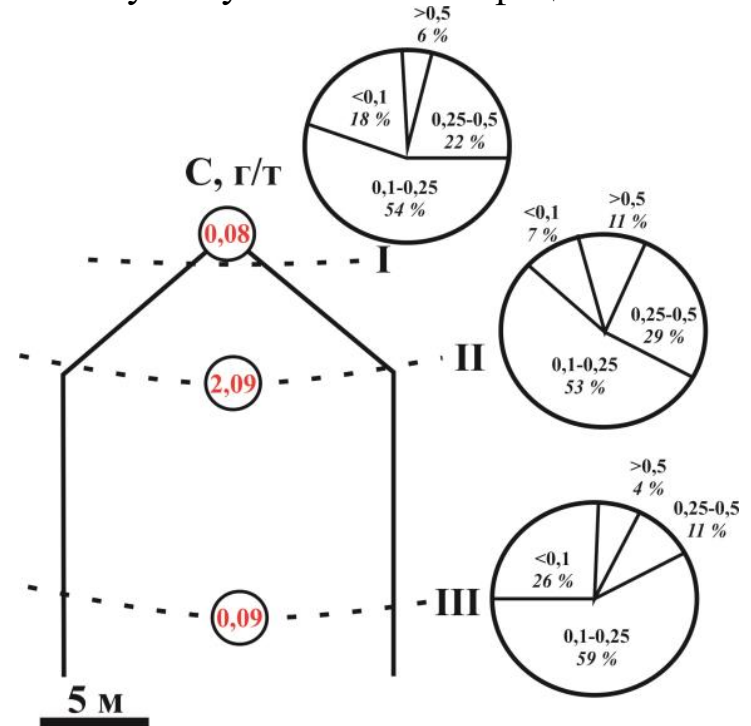

Рис. 1. Схема строения отвала месторождения Тардан с диаграммами распределения содержания золота по классам (мм) и значениями содержаний $(C$, г/m): I - устьевая зона; II средняя часть; III - периферия

Сведения о месторождении (строение, морфология, вещественный состав, последовательность минералообразования) описаны многими исследователями (Шаповалов и др., 2008; Гаськов, 2008; Коробейников и др., 1976). Основную добычу коренного золота осуществляли из скарновой руды, в которой золото образовалось в микротрещинках и в межзерновых пустотах. На месторождении выделено 3 генерации золота: (i) золото из скарново-магнетитовых руд; (ii) золото из минерализованных зон; (iii) золото из фланговых участков минерализованных зон (Гаськов,2008; Шаповалов и др., 2008). Золото из скарново-магнетитовых руд (i) представлено мелкими и тонкими (0,3-0,01 мм) самородными выделениями, находится в свободном виде и в срастании с андрадитом, магнетитом, актинолитом, хлоритом, гематитом, кальцитом, кварцем, халькопиритом, борнитом, галенитом, висмутином, теллуровисмутитом, проявляя признаки своего более позднего отложения. Частицы золота разме- ром более 50 мкм в руде не обнаружены, основная их масса ( $75 \%)$ приходится на класс крупности менее 50 мкм. Формы золотин чаще тонколистоватые, тонкопластинчатые, бахромчатые, комковидно-губчатые, дендрито-листоватые, зерновидные и реже сростки кристаллов в форме (100), (110), (111) (Шаповалов и др., 2008). Это преимущественно высокопробное золото (820-990 \%о) с содержанием примеси серебра (до 13,6\%) и меди (до 5,07\%) (Гаськов, 2008). Для золота из минерализованных зон (ii) пробность изменяется в широком диапазоне - от 440 до 820 \%. Наиболее низкопробные выделения золота близки по составу к электруму и характеризуются, наряду с высокими содержаниями серебра (до 54,78\%), повышенной примесью ртути (до 3,65\%). Золото из фланговых участков минерализованных зон (iii) отличается низкой пробностью, не превышающей 600 \%. Главными примесями в нем является серебро, содержание которого изменяется от 20 до $66 \%$, и ртуть с содержанием до $5,47 \%$ (Гаськов, 2008). Содержание золота в скарновой руде составляет 6 г/т (Шаповалов и др., 2008). Поверхность основной массы золотин абсолютно чистая, однако, отмечаются зерна в сростках с гидроксидами железа и силикатами.

\section{Методы исследования}

В ходе полевых работ студенческим отрядом Пермского государственного национального исследовательского университета в 2013 г. были отобраны три шлиховые пробы по профилю в направлении максимальной изменчивости условий накопления золота (Наумов, 1994, 2010) объемом 7 л каждая: в 0 м - зона 1, в 7 м - зона 2 и 17 м - зона 3 . Пробы обогащены на установке для мелких ценных минералов (МЦМ) по методике Пермского университета (Лунев и др., 1979; Лунев и др., 2011).

Последующие исследования были проведены в лаборатории осадочных полезных ископаемых. Концентрацию свободного гравитационного золота определяли путем измерения отношения массы извлеченного свободного гравитационного золота к объему исходной пробы. Содержание золота в магнетите и других минералах не изучали. При- 
менение ситового анализа позволило определить гранулометрический состав золота в пробах. Поверхность золота и морфологию частиц изучали с помощью электронного стереоскопа Nikon SMZ1500 NIS-Elements (Nikon, Япония).

Кроме того, были проведены исследования по определению пробности и химического состава золота с помощью микрозондового анализа на ED-спектрометре INCA ENERGY 350 («OxfordInstruments», Великобритания) на установке JSM 6390LV фирмы JEOL (аналитик проф. Б.М. Осовецкий, сектор «Наноминералогии ПГНИУ»).

\section{Результаты}

\section{1. Морфология золота}

В пробе из зоны I было обнаружено 54 знака золота. Содержание составило 77 $\mathrm{M \Gamma} / \mathrm{M}^{3}$. По данным ситового анализа, золото преобладает в классе 0,1-0,25 мм $(53,7 \%)$, меньше в классах 0,25-0,5 мм (22,2\%) и $<0,1$ мм (18,5\%) (рис. 1). Кроме того, обнаружены знаки золота в классе $>0,5$ мм $(5,6 \%)$, максимальный размер зерна составил 1,45 мм. Таким образом, основная масса благородного металла характеризуется как мелкое $(0,25-0,1$ мм), также присутствует тонкое (менее 0,1 мм). Цвет золотин различен. Встречаются зерна от яркого золотисто-желтого до бледно-желтого цвета. Часто наблюдаются частицы золота с коричневым, красным, серым оттенками, также отмечается ржавый налет в микротрещинах и на поверхности золотин.

Преобладающая масса частиц золота в пробе имеет неправильную форму, в меньшей степени наблюдаются идиоморфные выделения золота. Из идиоморфных выделений в пробе отмечаются золотины изометрического облика, а также плохо образованные, округлые и каплевидные кристаллы, размер которых колеблется от 0,04 до 0,09 мм. В целом на их долю приходится $11 \%$ от общего числа изученных золотин. К плохо образованным кристаллам относят округлые и каплевидные зерна, извилистые, амебообразные, лепешковидные, палочковидные. Контуры округлых зерен золота не подчиняются формам трещин.

Поверхность таких частиц чаще относительно ровная, сглаженная, иногда волнооб- разная, контуры краев округлые, неровные, зазубренные, иногда встречаются золотины с загнутыми краями. Отмечаются индивиды с деформированной поверхностью, а именно с «заклепками» (поперечно-свернутые фрагменты), которые не характерны для рудного золота. Поскольку изучаемый концентрат поступает в отвалы после гравитационного обогащения, можно предположить, что такие деформации могли возникнуть в результате столкновения частиц золота с более твердыми частицами и их трения, также в результате трения частиц о дно или стенки машины, в которой проводится обогащение. Сглаживание поверхности у частиц золота также можно отнести к преобразованиям, возникшим в процессе переработки руды.

В пробе встречаются частицы золота, которые располагались в брекчиях кварца и/или сульфидов. Они имеют комковидную форму. От простых трещинных форм их отличает отсутствие уплощенности, сложное, часто разветвленное строение. Комковидные частицы благородного металла представляют собой выделения сложной, иногда причудливой формы, от плотной центральной части в разные стороны отходят выклинивающиеся ответвления. Они напоминают комки пластичного вещества. На золоте встречаются различные формы ответвлений: островыклинивающиеся, тупые, обрывающиеся выступы, чаще с округленными концами. На некоторых зернах замечены округлые дырки.

Также среди изученных частиц золота некоторую часть (13\%) нельзя отнести к указанным выше морфологическим типам. Среди них отмечены дендритовые выделения, которые попадают в размерный диапазон от 0,2 до 0,4 мм.

В зоне II морфология золота несколько отличается. Эта зона формируется вблизи головной части хвостохранилища и является ее продолжением. Здесь намывной поток разделяется на несколько струй. Отмечено высокое содержание золота - $2085 \mathrm{Mг} / \mathrm{m}^{3}$. Для изучения морфологических особенностей благородного металла рассматриваемой зоны из всех зерен золота была отобрана представительная группа (100 зерен), включающая частицы разной крупности и формы.

Основная масса золота характеризуется как мелкое 0,25-0,1 мм (53\%). Менее всего 
частиц попадает на класс $<0,1$ мм (7\%) (рис. 1). На фоне мелкого золота выделяются несколько индивидов особо крупных размеров. Они отличаются уплощенным обликом, довольно гладкой и ровной поверхностью, имеющей трещинки и небольшие ямки, края окатанные. Характерен таблитчатый и пластинчатый облик.

В этой зоне намывного отвала доля уплощенных частиц золота составляет $36 \%$ общего числа. Среди них обнаружены пластинчатые (16\% общего числа изученных частиц золота) и таблитчатые (20\%) разности. Пластинчатые индивиды распространены среди частиц размером 0,35-0,7 мм, также отмечаются индивиды класса более 1,0 мм. Золотины с таблитчатым обликом наиболее характерны для класса 0,25-0,1 мм. В классе 0,25-0,45 также присутствуют индивиды с таблитчатым обликом, но уже в меньшей степени.

Главной морфологической особенностью золота в этой зоне намывного отвала является то, что в большей степени присутствуют частицы, представляющие собой слипшиеся, смятые агрегаты комковидной, причудливой формы, имеющие многочисленные включения чаще черного, белого полупрозрачного, зеленого, коричневого цветов. На их долю приходится $44 \%$ общего числа выборки. Такие агрегаты чаще встречаются в среднеразмерных классах (0,25-0,1 мм) - $68 \%$. Число данных агрегатов уменьшается с увеличением крупности: в классе 0,25-0,5 мм $21 \%$, в крупном классе $-11 \%$. В наиболее мелких классах $(<0,1$ мм) отмечаются частицы золота изометричного и удлиненного облика.

Частицы золота удлиненного облика игольчатые, проволоковидные, столбчатые и короткостолбчатые. Данная морфологическая группа характерна для золотин размером менее 0,15 мм и достигает $11 \%$ общего числа знаков. От частиц уплощенного облика их отличают также иной характер поверхности, неровность краев.

Меньше всего частиц золота изометрического облика - 9\% общего числа золотин. Попадаются преимущественно кристаллы размером 50 мкм, реже 75 мкм. В эту группу прежде всего попадают кристаллы золота округленной формы. Для них характерны иногда слабая уплощенность и другие искажения.

В зоне III было обнаружено 70 знаков зо-

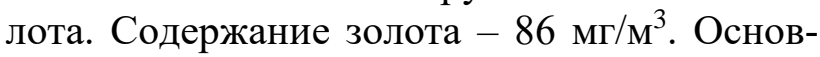
ная масса благородного металла характеризуется как мелкое - 0,25-0,1 мм (58,6 \%) и тонкое - значительно увеличивается число знаков менее 0,1 мм $(25,7 \%)$, в отличие от предыдущих проб. Значительно уменьшаются количество крупных зерен, класс $>0,5$ мм $(4,3 \%)$ и $0,25-0,5$ (11,4\%) (рис. 1). Максимальный размер частиц золота составляет 0,65 мм.

Наибольшую распространенность имеют частицы уплощенного облика (49\%). Среди них обнаружены пластинчатые (10\% общего числа изученных золотин) и таблитчатые (39\%) разности. Пластинчатые индивиды распространены среди частиц размером 0,250,575 мм. Зерна с таблитчатым обликом наиболее характерны для среднеразмерного класса $(0,25-0,1$ мм), в более крупных класcax их количество уменьшается. Частицы уплощенного облика в большей степени свернуты и изогнуты, наряду с этим встречаются зерна с гладкой и ровной поверхностью, ровными краями.

Золото изометричного облика составляет $11 \%$ общего числа знаков. У зерен данной морфологической группы отмечаются преимущественно округлая форма, слабая уплощенность, неровная поверхность. Кристаллы встречаются размером не более 75 мкм.

Меньше всего в пробе зерен с неправильной клиновидной формой (4\%). Они характеризуются ровными краями, уплощенностью, ямчатой поверхностью, размером до 0,15 мм.

Наибольшее морфологическое разнообразие представляют золотины «агрегатного» строения. На их долю приходится 23\% изученных частиц. Их размер колеблется от 0,125 до 0,5 мм. Агрегаты золота принимают причудливую, неправильную форму, часто изогнуты, края подогнуты, поверхность золотин неровная, кавернозная, с ямками, пустотами, иногда присутствуют включения других минералов. Края зазубренные, бахромчатые, иногда окатанные.

Помимо свободного золота, наблюдаются сростки золота с другими минералами $(7,1 \%$ 
общего числа частиц). Предположительно такие индивиды сохранили первоначальную форму.

\section{2. Гранулометрический состав и распре-} деление концентраций золота вдоль отвала

Распределение по крупности частиц золота из коренных руд и отвала в целом по спектру размера золотин сходно (табл.1, рис. 1). Вместе с тем происходит закономерное увеличение размера частиц золота вдоль профиля намывного отвала. Это объясняется процессами дифференциации золота, изби- рательным выносом мелкого и тонкого золота за пределы участка его накопления.

Для количественной характеристики дифференциации золота по крупности в отвалах относительно коренного источника рассмотрены показатели их гранулометрического состава и введено понятие коэффициент накопления золота (Кн) размерной фракции в точке опробования. Коэффициент характеризует отношение содержания размерной фракции золота из точки опробования отвала к содержанию одноименной фракции рудного золота (табл. 2).

Таблица 1. Гранулометрическая структура свободного золота коренных руд и техногенных отвалов

\begin{tabular}{|c|c|c|c|c|c|}
\hline \multirow{2}{*}{ Источник золота } & \multicolumn{4}{|c|}{ Фракция, мм } & \multirow{2}{*}{$\mathrm{C}, \boldsymbol{\Gamma} / \mathbf{M}$} \\
\hline & $>0,5$ & $0,25-0,5$ & $0,1-0,25$ & $<0,1$ & \\
\hline Рудного - скарны* & 1,0 & 10,0 & 80,0 & 9,0 & 2,80 \\
\hline Зона I** & 5,6 & 22,2 & 53,7 & 18,5 & 0,08 \\
\hline Зона II** & 11,0 & 29,0 & 53,0 & 7,0 & 2,09 \\
\hline Зона III** & 4,3 & 11,4 & 58,6 & 25,7 & 0,09 \\
\hline
\end{tabular}

Примечание. * - золото выделено гравитационными методами, данные из работы (Коробейников, Кузьмин, 1970); ** -данные ПГНИУ $(2013,2014)$; С - содержание золота, г/м³

Таблица 2. Коэффициент накопления золота в техногенных осадках по размерным фракциям, по количеству раз

\begin{tabular}{|c|c|c|c|c|}
\hline \multirow{2}{*}{ Кн } & \multicolumn{4}{|c|}{ Фракция, мм } \\
\cline { 2 - 5 } & $>\mathbf{0 , 5}$ & $\mathbf{0 , 2 5 - 0 , 5}$ & $\mathbf{0 , 1 - 0 , 2 5}$ & $<\mathbf{0 , 1}$ \\
\hline Зона I**/ рудное* & 5,6 & 2,2 & 0,7 & 2,1 \\
\hline Зона II**/ рудное* & 11,0 & 2,9 & 0,7 & 0,8 \\
\hline Зона III**/ рудное* & 4,3 & 1,1 & 0,7 & 2,9 \\
\hline
\end{tabular}

Примечание. **См. в табл. 1.

Таким образом, мы видим, что в результате механической дифференциации вещества при транспортировке частиц золота вдоль отвала происходит перераспределение его концентраций и изменение содержания размерных фракций. В целом для гравитационных отвалов характерно некоторое увеличение доли относительно крупного класса (0,1-0,5 мм) по сравнению с рудной зоной. Повышенная концентрация металла определена не в зоне боя потока, а в 7 м от зоны поступления осадков на отвал. На этом участке создавались благоприятные условия соответствия динамики водного потока и гидравлической крупности частиц металла. В устьевой зоне (участок поступления осадков в гидроотвал) частицы классов более 0,25 мм накапливаются, класс 0,1-0,25 мм избирательно выносится. В 17 м от устья накапливаются частицы менее 0,1 мм, 0,1-0,25 мм; частицы крупнее 0,25 мм практически не выносятся дальше по профилю.

Дополнительным фактором распределения концентраций золота по телу отвала является высокое (1-10\%) содержание магнетита. При намагничивании они образуют агрегаты с большей, чем у частиц золота, гидравлической крупностью и могут вытеснять частицы золота.

Низкая концентрация, выявленная в головной части отвала, не является типичной для намывных отвалов. Известно, что основная закономерность распределения свободного гравитационного золота в намывных 
массивах - это приуроченность наиболее высоких концентраций золота к устью сбросных пульповодов (Макаров, 2001; Наумов, 1994, 2010).

\section{3. Химический состав частиц золота}

Для определения химического состава золота из «хвостов» использован микрозондовый анализ (аналитик проф. Б.М. Осовецкий). Было изучено 19 знаков золота, которые имеют достаточно широкий диапазон пробности (328 - 980\%), указывающий на то, что присутствует золото из разных минерализованных зон. Кроме того, мы обнаружили как однородные по составу золотины, так и частицы с зональным строением - высокопробными каймами и прожилками (рис.

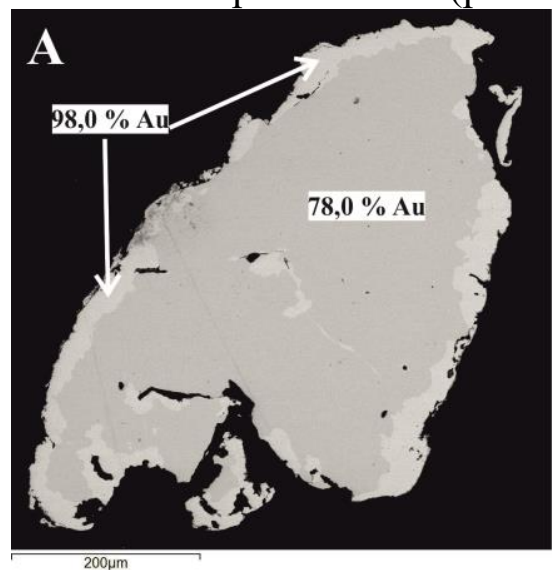

2,А). Также в золотинах отмечены включения минералов на поверхности, например висмутит, и внутри частицы - висмут, включения минералов борнита, внутри частицы и на поверхности - кальцит (рис. 2,Б).

Полученная картина многообразия элементов-примесей - $\mathrm{Cu}, \mathrm{Ag}, \mathrm{Fe}, \mathrm{Hg}, \mathrm{Co}, \mathrm{Bi}, \mathrm{Pd}$ (табл. 3) и пробности частиц золота (табл. 4) свидетельствует о том, что в отвал поступало золото разных генераций. Вместе с тем можно выявить тенденцию к уменьшению содержания золота в частицах по мере удаления от участка его поступления в отвал. Это может быть объяснено снижением его гидравлической крупности по мере удаления от зоны боя потока.

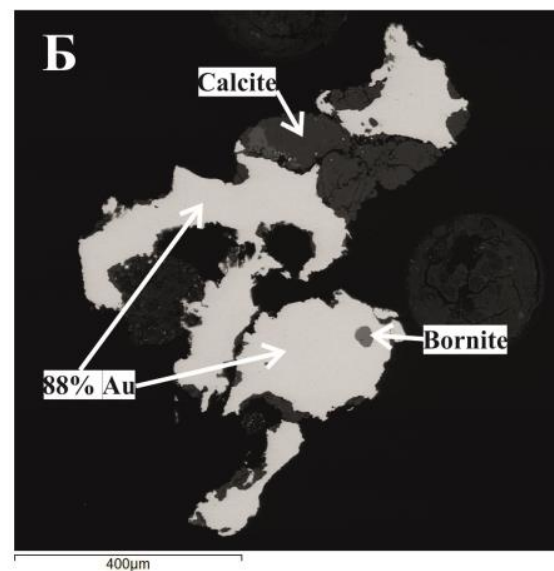

Рис. 2. Внутреннее строение золотин: $A$ - золотина с каймами высокопробного золота; $Б$ - золотина с включениями кальцитта на поверхности и борнита внутри частиць

Таблица 3. Элементы-примеси в золоте из техногенных отвалов

\begin{tabular}{|c|c|c|c|c|c|c|c|c|c|c|c|}
\hline $\begin{array}{c}\text { Источник } \\
\text { золота (N } \\
\text { анализов) }\end{array}$ & $\mathbf{A u}$ & $\mathbf{A g}$ & $\mathbf{C u}$ & $\mathbf{F e}$ & $\mathbf{H g}$ & $\mathbf{C o}$ & $\mathbf{B i}$ & $\mathbf{P d}$ & $\mathbf{Z n}$ & $\mathbf{A l}$ & $\mathbf{A s}$ \\
\hline Зона I** & 81,11 & 9,39 & 6,75 & 2,07 & 0,19 & 0,03 & 0 & 0 & 0,37 & 0,05 & 0,01 \\
\hline Зона II** & 79,84 & 12,43 & 1,50 & 3,65 & 0 & 0 & 2,31 & 0,25 & 0 & 0 & 0 \\
\hline Зона III** & 70,97 & 9,84 & 14,20 & 3,84 & 0,55 & 0 & 0,48 & 0,13 & 0 & 0 & 0 \\
\hline
\end{tabular}

Примечание. **См. в табл. 1.

Таблица 4. Элементы-примеси в коренном золоте и из техногенных отвалов

\begin{tabular}{|c|c|c|c|}
\hline \multirow{2}{*}{ Источник золота (N анализов) } & \multicolumn{3}{|c|}{ Химические элементы, $\%$} \\
\cline { 2 - 4 } & $\mathbf{C u}$ & $\mathbf{A g}$ & $\mathbf{A u}$ \\
\hline Скарны (15)* & 0,02 & 5,90 & 94,10 \\
\hline Зона I (10)** & 6,75 & 9,39 & 81,11 \\
\hline Зона II (5)** & 1,50 & 12,43 & 79,84 \\
\hline Зона III (4)** & 14,20 & 9,84 & 70,97 \\
\hline
\end{tabular}

Примечание. **См. в табл. 1 .

\section{Обсуждение}

Распределение и концентрирование золота вдоль профиля отвала произошло из то- чечного участка поступления при ведущей роли процесса дифференциации осадков и благородного металла.

Впервые понятие об осадочной диффе- 
ренциации ввел в литологию Л.В. Пустовалов (1940), разделив на процессы природной дифференциации вещества осадков по крупности, плотности, химическому составу. В результате исследования типоморфных признаков золота из отвалов мы видим, что наиболее ярко проявлена механическая дифференциация. Данный процесс заключается в сортировке обломочных частиц по величине, плотности и форме зерен, а дальность переноса зависит от формы частиц (Пустовалов, 1940; Рухин, 1969) или, более точно, от соотношения энергетики потоков и гидравлической крупности переносимых частиц.

Ранее были показаны результаты более детальных исследований механической дифференциации золота при формировании намывных техногенно-минеральных образований на разных объектах разработки россыпного и рудного золота разных классов крупности, в том числе частиц мелкого и тонкого золота (Наумов, 1988, 1994, 2010; Лунев и др., 2000, 2003; Наумов и др., 2010). Полученные результаты подтверждают этот процесс, как и характеристика трех точек опробования с разными условиями концентрирования золота: ближней с золотом крупным и в сростках с другими минералами, средней (переходная) и дальней с мелким и тонкодисперсным золотом. По аналогии происходят образование и распределение вещества в аллювиальных (Пустовалов, 1940; Рухин, 1969; Лунев, 1967; Осовецкий, 1983; Shusteret. al., 2017) и техногенных отложениях (Наумов, 2010; Макаров, 2001; Шило, 2002).

Опосредованно, через механическую дифференциацию, проявляется и химическая дифференциация частиц золота. Другим аспектом химической дифференциации вмещающего золото осадка является последовательное осаждение химически растворенных соединений из водных растворов. Переход растворенных веществ в твердую фазу происходит под влиянием внешних факторов (температура, давление, газовый режим, щелочно-кислотные и окислительновосстановительные свойства среды), интенсивность которых определяется температурно-климатическими условиями среды. Результатом данных преобразований является формирование пленок различного состава, например, гидроксидов железа и марганца (Наумов, 2010).

Физико-химическая дифференциация связана с коллоидной фазой, а именно в результате процессов коагуляции коллоидных растворов и явления сорбции происходят цементация, укрупнение и преобразование минерального состава вещества. Не исключено, что химическая дифференциация осадков способствовала образованию агрегатов золота, которые присутствовали в хвостохранилище.

Другим видом является хемобиогенная и биогенная дифференциации, суть которых заключается в осаждении и дифференциации вещества благодаря жизнедеятельности организмов. Существует много примеров, доказывающих существенную роль биоты в формировании и образовании золота и других минералов (Куимова, 2004; Shuster et al., 2018).

\section{Заключение}

Эволюция преобразования золота в экзогенной среде, а именно формирование его гранулометрической структуры и химического состава, прямо зависит от золота, поступающего из природного источника, технологии отработки и физико-химических и биогенных условий среды.

Поступление золота в отвалы происходит вследствие его неполного извлечения промышленными приборами. Распределение золота в отвалах имеет закономерный характер, обусловленный благоприятным сочетанием показателей гидравлической крупности частиц и динамических параметров потоков.

\section{Библиографический список}

Гаськов И.В. Новые данные о соотношении скарновой и золоторудной минерализации на Тарданском месторождении (Северо-Восточная Тува) // Геология и геофизика. 2008. Т. 49, №12. C. 1227-1237.

Жмодик С.М., Калинин Ю.А., Росляков Н.А. и $\partial p$. Наночастицы благородных металлов в зоне гипергенеза // Геология рудных месторождений. 2012. T. 54, №2. С. 141-154.

Коробейников А.Ф., Мацюшевский А.В. Золото в интрузивных и контактово-метасоматических 
породах Тарданского скарнового поля Тувы // Геохимия. 1976. № 9. С. 1409-1416.

Куимова Н.Г Аккумуляция и кристаллизация золота микроорганизмами, выделенными из рудных и россыпных месторождений / Рос. акад. наук, Дальневост. отд-ние, Амур. науч. центр, ботан. сад. Владивосток: Дальнаука, 2004. 133 с.

Лунев Б.С. Дифференциация осадков в современном аллювии // Учен. зап. Пермского ун-та. 1967. № 174. 333 c.

Лунев Б.С., Наумов В.А., Наумова О.Б. Мелкие ценные минералы в аллювии Пермского края // Естественные и технические науки. 2011. № 3. C. 262.

Лунев Б.С., Осовеиякий Б.М. Методика поэтапного изучения мелкого золота // Колыма. Магадан, 1979. №11. С.36-37.

Лунев Б., Наумов В.А.Мелкое золото - главное золото нашей планеты // Геология и полезные ископаемые Западного Урала. Пермь, 2000. C. $52-56$.

Лунев Б.С., Наумов В.А., Наумова О.Б. Мелкие ценные минералы в аллювии // Известия высших учебных заведений. Горный журнал. 2003. № 6. C.53.

Макаров B.A. Условия формирования техногенных золотосодержащих объектов и особенности методики их геолого-технологической оценки: автореф. дис. ... докт. геол.-мин. наук. Красноярск, 2001. 33 с.

Наумов В.A. Минерагения, техногенез и перспективы комплексного освоения золотоносного аллювия: автореф. дис... докт. геол.-мин. наук/ Перм. гос. ун-т. Пермь, 2010.

Наумов В.А. Процессы формирования и распределения концентраций благородных металлов в техногенных россыпях и отвалах Урала // Горный журнал. Уральское горное обозрение. Екатеринбург, 1994. N8. C. 39-50.

Наумов В.А., Лунев Б.С., Наумова О.Б. Мелкие ценные минералы россыпей // Известия высших учебных заведений. Северо-Кавказский регион. Серия: Естественные науки. 2010. № 4 (158). C. 123-126.

Наумов В.А., Наумова О.Б., Фиоруччи А. Перспективы освоения золота из природных и техногенно-минеральных образований Западного Урала // Геология и полезные ископаемые Западного Урала. 2018. №1 (38). С. 65-71.

Николаева Л.А., Гаврилов А.М., Некрасова A.H. $u$ дp. Типоморфизм самородного золота/ ЦНИГРИ. М., 2003. 70 с.

Осовеикий Б.М. Тяжелая фракция аллювия. Иркутск, 1986.

Осовецкий Б.М. Наноскульптура поверхности золота. Пермь, 2012. 232 с.

Петровская Н.В. Самородное золото. М.: Наука, 1973. 348 с.

Пустовалов Л.В. Петрография осадочных пород. М.; Л.: Гостоптехиздат, 1940. Ч. І.

Рухин Л. Б. Основы литологии. Л.: Недра, $1969.704 \mathrm{c}$.

Сафронов П.П., Кузнецова И.В. Особенности состава самородного золота техногенных россыпей на примере Нижнеселемджинского золотоносного узла (Приамурье) // Известия Томского политехнического университета. Инжиниринг георесурсов. 2017. Т. 328 (2). С. 46-58.

Шило Н.А. Учение о россыпях. Теория россыпеобразующих рудных формаций и россыпей. Владивосток: Дальнаука, 2002. 576с.

Chapman R.J., Mortensen, J.K. Characterization of Gold Mineralization in the Northern Caliboo Gold District, British Columbia, Canada, Through Integration of Compositional Studies of Lode And Detrital Gold With Historical Placer Production: A Template for Evaluation of Orogenic Gold Districts// Econ. Geol. 2016. Vol. 111 (6). P. 1321-1345.

Craw D., MacKenzie D., Grieve P. Supergene Gold Mobility in Orogenic Gold Deposits, Otago Schist, New Zealand. New Zealand // Journal of Geology and Geophysics. 2015. Vol. 58 (2). P.123-136.

Friese F.W. The transportation of gold by organic underground solutions// Econ. Geol. 1931.Vol. 26 (4). P. 421-431.

Myagkaya I.N., Lazareva E.V., Gustaytis M.A., Zhmodik S.M. Gold and Silver in a System of Sulfide Tailings. Part 1: migration in water flow // Journal of Geochemical Exploration. 2016. Vol. 160. P. 16-30.

Reith F., Shuster J. Reflecting on Gold Geomicrobiology Research: Thoughts and Considerations for Future Endeavors // Minerals. 2018. Vol. 8(9). P. 401.

Shuster J., Reith F., Cornelis G., Parsons J.E., Parson J.M., Southam G. Secondary Gold Structures: Relics of Past Biogeochemical Transformations and Implications for Colloidal Gold Dispersion in Subtropical Environments// Chem. Geol. 2017. Vol. 450. P. 154-164.

Wierchowieca J., Mikulskib S.Z., Gąinísk A. Nanoforms of Gold from Abandoned Placer Deposits of WądrożeWielkie, Lower Silesia, Poland - The Evidence of Authigenic Gold Mineralization // Ore Geology Reviews. 2018. Vol. 101. P. 211-220.

Wierchowiec J., Wojciechowski A. Auriferous Wastes from the Abandoned Arsenic and Gold Mine in Złoty Stok (Sudetes Mts., SW Poland) // Geological Quarterly. 2009. T. 53, № 2. P. 233-240. 


\title{
Differentiation of Gold Particles after Gravity Concen- tration (Tardan Deposit, Tuva Republic, Russia)
}

\author{
A.Sh. Khusainova ${ }^{1}$, V.A. Naumov ${ }^{2,3}$, O.B. Naumova ${ }^{2}$
}

${ }^{1}$ Sobolev Institute of Geology and Mineralogy of the Russian Academy of Sciences (IGM SB

RAS), 3 Akademika Koptyuga Ave., Novosibirsk 630090, Russia. E-mail: khusainova@igm.nsc.ru

${ }^{2}$ Perm State University, 15 Bukirev Str., Perm 614990, Russia. E-mail: poisk@psu.ru

${ }^{3}$ Natural Sciences Institute, Perm State University, 4 Genkel Str., Perm 614005, Russia. E-mail: naumov@psu.ru

We conducted an analysis, generalization, and comparison of content, granulometric and chemical composition, and morphology of lode gold from the Tardan deposit as well as from the tailings of the ore gold gravity concentration. It was established that the particles with less fall velocity than those from dominant part of the ore gold are delivered in tailings. Alteration of gold in exogenic conditions (formation of the granulometric structure and chemical composition) depends on the characteristics of ore gold, processing technology, and physical-chemical, and biogenic conditions formed in the concentration wastes medium.

Key words: technogenic processes; supergene processes; tailings; gold.

\section{References}

Gaskov I.V. 2008. Novye dannye o sootnoshenii skarnovoy i zolotorudnoy mineralizatsii na Tardanskom mestorozhdenii (Severo-Vostochnaya Tuva) [New data on the relationship of skarn and gold mineralization at Tardan deposit (North-East Tuva)]. Geologiya i geofizika. 49(12):1227-1237. (in Russian)

Zhmodik S.M., Kalinin Yu.A., Roslyakov N.A. et al. 2012. Nanochastitsy blagorodnykh metallov $\mathrm{v}$ zone gipergeneza [Nanoparticles of noble metals in hypergenesis zone]. Geologiya rudnykh mestorozhdeniy. 54(2):141-154. (in Russian)

Korobeynikov A.F., Matsyushevskiy A.V. 1976. Zoloto $\mathrm{v}$ intruzivnykh i kontaktovo-metasomaticheskikh porodakh Tardanskogo skarnovogo polya Tuvy [Gold in the intrusive and contact-metasomatic rocks of the Tardan skarn field of Tuva]. Geokhimiya. 9:1409-1416. (in Russian)

Kuimova N.G. 2004. Akkumulyatsiya i kristallizatsiya zolota mikroorganizmami, vydelennymi iz rudnykh i rossypnykh mestorozhdeniy [Accumulation and crystallization of gold by the microorganisms retrieved from lode and placer deposits]. RAN DVO, Amur. nauch. tsentr, botan. sad. Vladivostok, Dalnauka, p. 133. (in Russian)

Lunev B.S. 1967. Differentsiatsiya osadkov v sovremennom allyuvii [Differentiation of sediments in modern alluvium]. Uchen. zap. Permskogo univ. Perm, v. 174, p. 333. (in Russian)

Lunev B.S., Naumov V.A., Naumova O.B. 2011. Melkie tsennye mineraly v allyuvii Permskogo kraya [Fine noble minerals in alluvium of Permskiy kray]. Estestvennye i tekhnicheskie nauki. 3:262. (in Russian)

Lunev B.S., Osovetskiy B.M. 1979. Metodika poetapnogo izucheniya melkogo zolota [Methodics of sequential study of fine gold]. Kolyma. Magadan, 11:36-37. (in Russian)

Lunev B.S., Naumov V.A. 2000. Melkoe zoloto glav-noe zoloto nashej planety [Fine gold is the main gold of our planet]. In: Geologiya i poleznye iskopaemye Zapadnogo Urala. pp. 50. (in Russian)

Lunev B.S., Naumov V.A., Naumova O.B. 2003. Melkie tsennye mineraly $\mathrm{v}$ allyuvii [Small valuable minerals in alluvium]. Izvestiya vysshikh uchebnykh zavedeniy. Gornyy zhurnal. 6:53 (in Russian).

Makarov V.A. 2001. Usloviya formirovaniya tekhnogennykh zolotosoderzhashchikh obyektov i osobennosti metodiki ikh geologotekhnologicheskoy otsenki [Conditions for the formation of technogenic gold-bearing objects and features of the methodology for their geological and technological assessment]. Dis. Dr. geol.-min. nauk. Krasnoyarsk. (in Russian)

Naumov V.A. 2010. Minerageniya, tekhnogenez i perspektivy kompleksnogo osvoeniya zolotonosnogo allyuviya [Minerageny, technogenesis and prospects for the integrated development of gold-bearing alluvium]. Diss. Dr. geol.-min. nauk. Permskii gosudarstvennyy universitet. Perm. (in Russian)

Naumov V.A. 1994. Protsessy formirovaniya i raspredeleniya kontsentratsiy blagorodnykh metallov $\mathrm{v}$ tekhnogennykh rossypyakh i otvalakh Urala [The processes of formation and distribution of concentrations of precious metals in industrial placers and dumps of the Urals]. Gornyy zhurnal. 8:39-50. (in Russian)

Naumov V.A., Lunev B.S., Naumova O.B. 2010. Melkie tsennye mineraly rossypey [Fine valuable minerals of placers]. Izvestiya vysshikh uchebnykh zavedeniy. Severo-Kavkazskiy region. Seriya: Estestvennye nauki. 4(158):123-126. (in Russian)

Naumov V.A., Naumova O.B., Fiorucci A. 2018. Perspektivy osvoeniya zolota iz prirodnykh i tekhnogenno-mineralnykh obrazovaniy Zapadnogo 
Urala [Prospects for the development of gold from natural and technogenic mineral formations of the Western Urals]. Geologiya i poleznye iskopaemye Zapadnogo Urala. 1(38):65-71. (in Russian)

Nikolaeva L.A., Gavrilov A.M., Nekrasova A.N. et al. 2003. Tipomorfizm samorodnogo zolota [Typomorphism of native gold]. TsNIGRI. Moskva, p. 70. (in Russian)

Osovetskiy B.M. 1986. Tyazhelaya fraktsiya allyuviya [Heavy fraction of alluvium]. Irkutsk. (in Russian)

Osovetskiy B.M. 2012. Nanoskulptura poverkhnosti zolota [Nano sculpture of the gold surface]. Perm. State Univ., Perm, p. 232. (in Russian)

Petrovskaya N.V. 1973. Samorodnoe zoloto [Native gold]. Nauka, Moskva, p. 348. (in Russian)

Pustovalov L.V. 1940. Petrografiya osadochnykh porod [Petrography of sedimentary rocks]. Gostoptekhizdat, M.-L. T. I. (in Russian)

Rukhin L.B. 1969. Osnovy litologii [The basics of lithology]. Nedra, Leningrad, p. 704. (in Russian)

Safronov P.P., Kuznetsova I.V. 2017. Osobennosti sostava samorodnogo zolota tekhnogennykh rossypey na primere Nizhneselemdzhinskogo zolotonosnogo uzla (Priamurie) [Compositional features of native gold of technogenic placers on the example of the Nizhne-Selemdzhinskiy gold-bearing cluster (PreAmur Region)]. Izvestiya Tomskogo politekhnicheskogo universiteta. Inzhiniring georesursov, 328(2):46-58. (in Russian)

Shilo N.A. 2002. Uchenie o rossypyakh. Teoriya rossypeobrazuyushchikh rudnykh formatsiy i rossypey [Treatise on placers. Theory of placer-forming ore formations and placers]. Dalnauka, Vladivostok, p. 576. (in Russian)
Chapman R.J., Mortensen, J.K. 2016. Characterization of Gold Mineralization in the Northern Caliboo Gold District, British Columbia, Canada, Through Integration of Compositional Studies of Lode and Detrital Gold with Historical Placer Production: A Template for Evaluation of Orogenic Gold Districts. Econ. Geol. 111(6):1321-1345.

Craw D., MacKenzie D., Grieve P. 2015. Supergene Gold Mobility in Orogenic Gold Deposits, Otago Schist, New Zealand. New Zealand. Journal of Geology and Geophysics. 58(2):123-136.

Friese F.W. 1931. The transportation of gold by organic underground solutions. Econ. Geol. 26(4): 421-431.

Myagkaya I.N., Lazareva E.V., Gustaytis M.A., Zhmodik S.M. 2016. Gold and Silver in a System of Sulfide Tailings. Part 1: migration in water flow. Journal of Geochemical Exploration. 160:16-30.

Reith F., Shuster J. 2018. Reflecting on Gold Geomicrobiology Research: Thoughts and Considerations for Future Endeavors. Minerals. 8(9):401.

Shuster J., Reith F., Cornelis G., Parsons J.E., Parson J.M., Southam G. 2017. Secondary Gold Structures: Relics of Past Biogeochemical Transformations and Implications for Colloidal Gold Dispersion in Subtropical Environments. Chem. Geol. 450:154-164.

Wierchowieca J., Mikulskib S.Z., Gąsińsk A. 2018. Nanoforms of Gold from Abandoned Placer Deposits of Wądroże Wielkie, Lower Silesia, Poland - The Evidence of Authigenic Gold Mineralization. Ore Geology Reviews. 101:211-220.

Wierchowiec J., Wojciechowski A. 2009. Auriferous Wastes from the Abandoned Arsenic and Gold Mine in Złoty Stok (Sudetes Mts., SW Poland). Geological Quarterly. 53(2):233-240. 